\title{
Validating an instrument for measuring brand equity of CSR driven organizations in Malaysia
}

\author{
Karpal SINGH DARA SINGH \\ Sentral College Penang, Malaysia \\ kirpal005@yahoo.com \\ Md. Aminul ISLAM \\ University Malaysia Perlis, Malaysia
}

\begin{abstract}
The objective of this study is to develop and propose a valid and reliable instrument to measure brand equity of CSR driven organizations in Malaysia. An instrument to measure brand equity was constructed with adaptations from two key sources, namely Yew Leh and Lee (2011) and Yoo and Donthu (2001). As such the study only focuses on the development and validation of an instrument to measure brand equity of CSR driven organizations. The usable sample population included 909 respondents from 12 states of West Malaysia which were selected using a quota sampling plan. Confirmatory factor analysis (CFA) and reliability analysis were carried out to test and validate the proposed brand equity instrument containing four components (brand awareness, brand association, perceived quality and brand loyalty) with a total of 13 items. Results from the CFA and reliability analysis indicated that all the items representing the four components were valid and can be used to measure the brand equity of organizations that are practicing CSR. The study tried to set an empirical basis for brand equity and CSR related research which could be used by future researchers in different industries and geographical locations. The study also implies the need for organizations to assess the success of their CSR efforts through the use of the proposed instrument in order to gauge whether all their CSR efforts translate to improved brand equity.
\end{abstract}

Keywords: brand equity, consumer based brand equity model, corporate social responsibility, consumers, Malaysia.

Please cite the article as follows: Singh Dara Singh, K. and Islam, A. Md. (2017), "Validating an instrument for measuring brand equity of CSR driven organizations in Malaysia", Management \& Marketing. Challenges for the Knowledge Society, Vol. 12, No. 2, pp. 237-251. DOI: 10.1515/mmcks-2017-0015.

\section{Introduction}

Brand equity refers to the value customers assign on the brand based on their perception about price, quality, service and product attributes. All these are factors that make a brand all that more appealing and influences consumer buying behavior. Building brand image or equity through corporate social responsibility (CSR) is not at all about opening a checkbook. It is about starting out with a value oriented philosophy as the foundation blocks of a brand. The consumers of today expect organizations to help change the world, even in the smallest of ways. It is common knowledge that a good brand is a reflection of quality, price, service and attributes of a product that helps to distinguish one product from another.

However, being in the information age customers often explore other factors as well in aiding their purchase decision. Fan (2005) argues that customer buying 
behaviour is not necessarily based on product and service quality or price perception but also on how ethical the company has performed in manufacturing its products and services. A good brand must provide a positive impact on its owner and user and also ensure that there is no negative impact on the general public. It means that brands must contribute positively to society by inserting ethical values, especially in the broader social context. Thus, a positive association of the brand with the general public will result. This is corroborated by Hoq et al. (2010) that an ethical brand has a positive effect on corporate reputation.

Organizations keen about developing an ethical brand image are mostly doing so through the CSR route, as CSR is often seen as an applied aspect of business ethics. The scope of business ethics lies in the responsibility an organization has towards the society or what is commonly known as corporate social responsibility. CSR theorists argue that management should incorporate ethics into strategic goals because it is the right thing to do (Wood, 1991). Past research is indicating that integrating ethics into the strategic management process not only is right, but is also the profitable thing to do (Key and Popkin, 1998). Nike has proved through its sweat shop blunder how much damage can be caused just because someone failed to notice the enormity of business ethics (Nisen, 2013). Brand image is affected, people become reluctant to patronize a brand and all these domino effect leads to a downhill on profits and sales.

Thus, it is very important that organizations never underestimate the impact of their social responsibility efforts. There has been substantial research evidence that CSR leads to improved corporate reputation, increased brand value and brand image. Lii (2011) found that CSR initiatives such as sponsorships, cause- related marketing and philanthropy leads to better association of the customer towards the organization's product and in turn build brand equity. A study by Zulhamri and Aziz (2013) revealed that CSR initiatives are significant predictors of dimensions of corporate reputation. Chen and Bouvein, (2005) revealed that CSR performance contributes to high brand value and improved Interbrand rankings while Maneet and Agrawal (2011) argued that CSR activities can enhance brand image. According to Tsao and Chen (2011), cause related marketing (CRM), one of the most common CSR initiatives, not only increases financial gains but can also enhance a company's image and reputation which are cornerstones of the brand equity model as proposed by Aaker (1991) and Keller (2008). Melo and Galan (2009) in their study involving 54 US based corporation found that CSR impacts positively on brand value.

Buil et al. (2013) proposed and tested a model to better understand brand equity and found that it had a positive effect on consumers' responses using data from two European countries. Managers should first build brand awareness as a means of improving perceived quality and positive brand association which according to Netemeyer (2004) is a core facet of consumer - based brand equity (CBBE) model. Brand equity is felt in all areas of production and promotion of a product and improved insight of the factors that build brand equity can lead to improved financial rewards to companies (Smith et al., 2007). 
Results provided empirical evidence of the benefits that brand equity can offer to companies. Brand equity is a significant predictor of positive consumer response. As such, the strengthening of brand equity is a vital strategy for companies seeking to improve their position in the markets. The researcher would like to assume that the underlying premise of this research to be that brand equity is a suitable measure of corporate performance. This postulation is consistent with Chu and Keh (2006), who stressed the prominence of corporate brand as a corporate performance metric; and with Fehle et al. (2008), who asserted that the best brands have hidden values, not priced by conventional asset pricing models. Yew Leh and Lee (2011) constructed a valid and reliable instrument to measure consumer based brand equity (CBBE) of Malaysian brands. The items in the instrument were very much based on past studies from Yoo and Donthu (2001) and Lassar et al. (1995). Results of their studies confirmed the items that were categorized in four factors (perceived quality, brand associations, brand loyalty and brand awareness) with a total of 14 items were valid to measure CBBE.

Across the broad spectrum many Malaysian organizations are shifting their attention to CSR. In its bid to encourage CSR practices, the government of Malaysia has even launched the Prime Minister's CSR award since 2007 to recognize companies that are making a difference through their Corporate Social Responsibility (CSR) programmes. However, organizations are really having a difficult time evaluating corporate social responsibility efforts because they are uncertain or rather unsure about the potential benefits and pay-offs. One of the ways to judge all these corporate social responsibility efforts is to ask the people who are touched by those efforts about how effective they are. How customers and other stakeholders include companies in their consideration set when they assess CSR of firms remains an area that has not been explored to any great extent by marketing scholars (Chen and Bouvain, 2005). There is a need to get it from the horse's mouth (so to speak) about whether CSR efforts really matter to them and would it lead to positive evaluations about the organization, its products and its brand. This paves the way for the research which focuses on the development of a valid and reliable instrument of measuring brand equity for organizations that are committed to CSR and have been undertaking various CSR efforts in recent years. This instrument could be used to measure whether CSR efforts undertaken by Malaysian organizations can translate into improved brand equity based on the perception of consumers.

\section{Literature review}

\section{Corporate social responsibility and branding}

Corporate social responsibility may be defined as "the commitment of businesses to contribute to sustainable economic development, working with employees, their families, the local community and society at large to improve their quality of life," (World Business Council for Sustainable Development, 2004). In the words of Hopkins (2006, p. 229), "CSR is concerned with treating the stakeholders of the firm ethically or in a socially responsible manner. Stakeholders exist both within a firm and outside. The aim of social responsibility is to create higher and higher standards 
of living, while preserving the profitability of the corporation, for its stakeholders both within and outside the corporation."

Netemeyer et al. (2001) found that the organizational association of being a "good corporate citizen" was related to willingness to pay a price premium for a brand and brand purchase which in turn increases brand equity. Ricks (2005) using an experimental design noted that consumers react positively to corporate philanthropy with no alternative intentions. Bhattacharya and Sen (2003) argued that consumers who identify with companies are more likely to be loyal to those companies, promote them to others, and be resilient to negative information about them.

Chen and Bouvain (2005) made comparisons relating to CSR rankings of highly valued brands (Interbrand Rankings) with companies having lower valued brands (Non-Interbrand Rankings). Results indicated that there is statistically significant difference between CSR rankings of Interbrand and non-Interbrand companies. It could be argued that instead of brand value leading to high CSR ranking, CSR performance contributes to high brand value and hence high Interbrand rankings (Chen and Bouvain, 2005). Melo and Galan (2009) argues that brand value is more sensitive to CSR than a market based performance indicator. Yin Fan (2005) contents that a corporate brand is a vital part of corporate reputation management. An ethical brand enhances the firm's reputation; such a reputation reinforces the brand in turn. Companies with meaningful brand images are characterized as having brand decision - makers who constantly update market information so as to evade brand erosion (Jurg et al., 2008). Market information is important in developing a distinctive brand image (O'cass and Ngo, 2007). Luu Trong (2012), offered an insight into the linkage pattern of CSR and brand equity and found that ethical CSR was positively associated with brand equity which was consistent with Kumar and George's (2007) argument that brand equity is impacted by brand awareness, attitude toward the brand and corporate ethics.

\section{Brand equity}

Brand equity is the added value endowed to products and services. Aaker (1991) defined brand equity as a set of brand assets and liabilities associated to a brand that adds or detracts the product or service value based on the customer's perspectives. This value may be reflected in the way consumers think, act and feel with respect to the brand that consumers perceive from marketing programs. Brand equity is an important intangible asset that has psychological and financial value to the firm. The value of brand equity depends on the number of people that buys it regularly (Aaker, 1991). He developed the following model to illustrate his definition: 


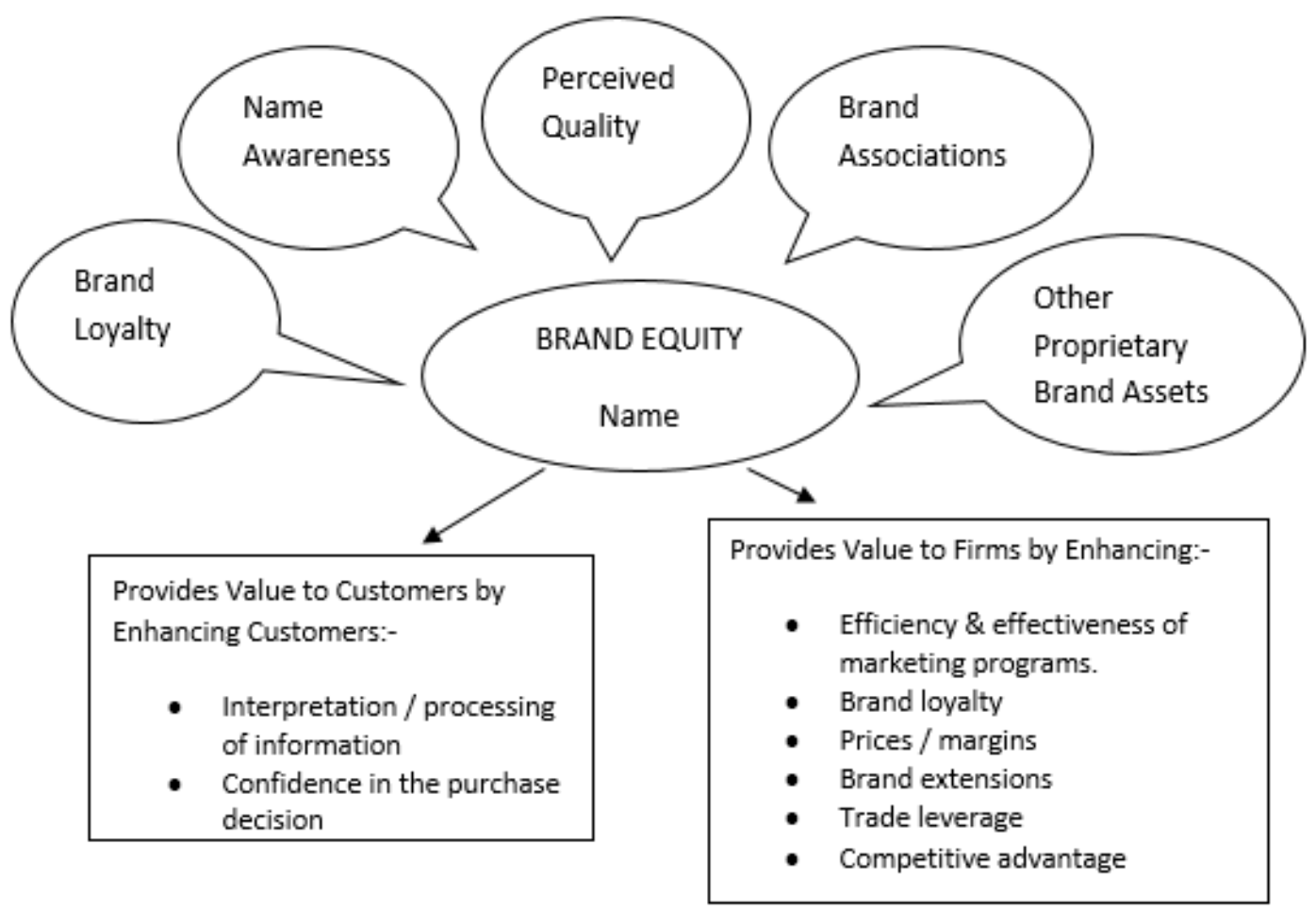

Figure 1. Aaker's brand equity model

Source: Aaker (1991).

Brand equity is based on a hierarchy of brand assets including awareness, feelings of familiarity, brand image, interest in purchase and/or investment, and customer loyalty. Some marketers confuse brand equity with brand image, but there is an important difference: brand equity contributes directly to the bottom line, but brand image on the other hand although contributes directly to the bottom line only helps build brand equity to a certain extent. Brand loyalty, brand awareness and brand perceived quality are found to be a must in sustaining brand equity (Motameni and Shahrokhi, 1998).

There are two different perspectives to brand equity: financial based and customer-based brand equity. The first perspective evaluates the asset value of a brand name to a business (Farquhar et al, 1991). Keller (1993) defines customerbased brand equity as the differential effect of brand knowledge on consumer response to the marketing of the brand. According to the evaluation based on consumer factors, the measurement of customer's preference and attitude can be used to measure brand equity (Aaker, 1991; Kapferer, 1992).

Customer - based brand equity (CBBE) refers to how marketing programs of a brand creates a differential outcome in brand knowledge among customers. There are three elements in building CBBE which are "differential effect", "brand knowledge" and "consumer responses" to marketing (Keller, 2008). However, Aaker's (1991, 1996) model of brand equity as illustrated in figure 1 has four important dimensions made up of perceived quality, brand association, brand awareness and brand loyalty. 
Yew Leh and Lee (2011), further expanded Aaker's (1991) model of brand equity by dividing and specifically identifying the major elements and contents of Aaker's (1991) four components brand equity model (which includes, brand awareness, brand associations, perceived quality and brand loyalty). Table 1 below summarizes the main components and variables of brand equity as discussed by Yew Leh and Lee (2011).

Table 1. Multidimensional brand equity variables

\begin{tabular}{|l|l|}
\hline Component & Variables \\
\hline Brand Awareness & 1. Brand Recognition \\
& 2. Brand Recall \\
& 3. Top - of - Mind \\
& 4. Brand Dominance \\
& 5. Brand Knowledge \\
\hline Brand Associations & 6. Reliability \\
& 7. Durability \\
& 8. Social Image \\
& 9. Trustworthiness \\
& 10.Perceived Value \\
& 11.Differentiation \\
& 12.Country of Origin \\
& 13.Corporate Ability \\
& 14.Corporate Social Responsibility \\
\hline Perceived Quality & 15. Extrinsic Attributes \\
& 16.Intrinsic Attributes \\
\hline Brand Loyalty & 17.Frequency of Repurchase \\
& 18.Top - of - mind \\
& 19.Price Premium \\
\hline
\end{tabular}

Source: Yew Leh, and Lee (2011, p. 39).

Yoo and Donthu (2001) whose work which perhaps precedes Yew Leh and Lee's (2011) work, expanded on Aaker's (1991) theory and developed a multidimensional consumer based brand equity scale which was validated and supported. The researchers proposed two scales namely the Multidimensional Brand Equity (MBE) and Overall Brand Equity (OBE) scales. The MBE scales mirrors Aaker's (1991) model consisting brand awareness, brand association and perceived quality and brand loyalty. The OBE scales on the other hand measures the overall end of customers evaluation towards a particular brand. The results of the research based on cross cultural demographic analysis reveals that the MBE and OBE scales are valid, reliable, and concise and can be implemented in several cultures for assessments of brand equity across products and services. Yoo and Donthu's (2001) valid instrument contains 10 items as indicators for measuring MBE and 4 items when measuring OBE which is shown in Table 2. 
Table 2. Ten - Item Multidimensional Brand Equity Scale

\begin{tabular}{|c|c|}
\hline 1. Brand Loyalty, the indicator is: & $\begin{array}{l}\text { a. I consider myself to be loyal of X (which refers to a } \\
\text { particular brand name). } \\
\text { b. X would be my first choice. } \\
\text { c. I will not buy other brands if X is available at the } \\
\text { store. }\end{array}$ \\
\hline 2. Perceived Quality, the indicator is: & $\begin{array}{l}\text { a. The likely quality of } X \text { is extremely high. } \\
\text { b. The likelihood that } X \text { would be functional is very } \\
\text { high. }\end{array}$ \\
\hline 3. Brand Awareness, the indicator is: & $\begin{array}{l}\text { a. I can recognize } X \text { among the other competing } \\
\text { brands. } \\
\text { b. X would be my first choice. }\end{array}$ \\
\hline 4. Brand Association, the indicator is: & $\begin{array}{l}\text { a. I can quickly recall the symbol or logo of X. } \\
\text { b. Some characteristics of X come to my mind quickly. } \\
\text { c. I have difficulty in imagining X in my mind } \\
\text { (reversed statement. }\end{array}$ \\
\hline \multicolumn{2}{|l|}{ Four items of overall brand equity: } \\
\hline $\begin{array}{l}\text { 1. It makes sense to buy X instead } \\
\text { 2. Even if another brand has the } \mathrm{s} \\
\text { 3. If there is another brand as goo } \\
\text { 4. If another brand is not different }\end{array}$ & $\begin{array}{l}\text { y other brand, even if they are the same. } \\
\text { eatures as X, I would prefer to buy X. } \\
\text { I prefer to buy X. } \\
\text { X in any way, it seems smarter to purcha }\end{array}$ \\
\hline
\end{tabular}

Source: Yoo, B. and Donthu, N. (2001, p. 11).

\section{Research methodology Conceptual framework}

To achieve the objective of the study, the researcher referred and made necessary adaptation to the brand equity instrument of Yoo and Donthu (2001) and Yew Leh and Lee (2011) in order to develop the questionnaire items to measure brand equity of CSR driven organizations. A total of 13 items were constructed to represent brand equity. Discussions supporting the development of the questionnaire items based on the four components of brand equity are presented in the following paragraphs.

\section{Brand awareness}

There are many factors that contribute to or makes up brand awareness. These include brand recognition, brand recall, top of mind, brand dominance and brand knowledge. Brand recognition literally refers to customers' ability to recognize the brand when they are exposed to certain elements of a brand which includes its name, logo, colours and etc. (Keller, 2008). Brand recall on the other hand refers to customer capability to remember particular brands when given something as a clue such as an occasion or a situation (Keller, 2008). Top of mind simply means that when people are aware of the brand it sets in the memory. It becomes easy to remember and lingers in the mind of the customers (Abraham, 2001). Brand dominance occurs when one particular brand becomes superior than its competitors (Subhani and Osman, 2011). Brand knowledge is attained from the 
brand identities (logo / symbol) and brand name which refers to the brand and helps distinguish it from the product category (Keller, 1993).

\section{Brand associations}

People associate with a product / service based on many factors. Yew Leh and Lee (2011) proposed that the factors of brand association comprises reliability, durability, social image, trustworthiness, perceived value, differentiation, country of origin, corporate ability and corporate social responsibility. The evaluation of a product performance by customers reflects the products functional attribute (Lassar et al., 1995) which can be divided into two parts; the products consistent performance through the years (reliability) and the products total life span (durability) (Keller, 2008). Non - functional product attributes on the other hand are more intangible and usually comprise of the products symbolic attribute which consist of social image, perceived value, trustworthiness, differentiation and country of origin effect on customers (Yew Leh and Lee, 2011).

\section{Perceived quality}

Perceived quality is felt from the products intrinsic attributes and extrinsic attributes. Intrinsic attributes are made up of physical characteristics such as taste, shape and appearance (Zeithamal 1988), where else, extrinsic attributes refer to anything than can be related to the product aside from the physical aspects which includes, the price, promotion, packaging and product information (Yew Leh and Lee, 2011).

\section{Brand loyalty}

Brand loyalty can be measured from frequency of repurchase, being in the top of mind and the willingness to pay a premium price. Keller (1998) and Oliver (1997) justified that loyalty really represents the amount of repeated purchase by the customer, which they referred to as the "commitment to rebuy the brand as a primary choice".

\section{Methodology}

The questionnaire was divided into two sections namely section A consisting 4 items (race, gender, employment sector and age) to obtain demographic data of respondents and section $B$ consisting 13 items on brand equity that were divided into four components namely, brand awareness (3items), brand association (4 items), perceived quality ( 3 items) and brand loyalty ( 4 items). The first section of the questionnaire used a nominal scale and in the subsequent sections, all items considered were measured on a 5-point Likert scale.

After completing the pre-testing process, survey questionnaires were then distributed to the sample population. The researcher targeted 100 respondents representing consumers from 12 states within the West of Malaysia bringing the total sample size to 1200 respondents, to make a valuable and reliable contribution to this study. According to Uma Sekaran (2000), in societies that are increasingly heterogeneous due to changing demographics, quota sampling can be expected to be 
used more frequently. This augurs well for the current research endeavor as Malaysia is a multi - racial country. Quota sampling would be helpful in ensuring that the sample is as representative as possible of the population being studied. The sample population would be divided in strata's according to the main ethnic groups in Malaysia (30\% Malays, 30\% Chinese, 30\% Indians and 10\% other ethnic minorities), gender (50\% males and 50\% females) and employment sectors (50\% from government sector and 50\% from the private sectors)

Data collection was carried out from the end of December 2013 till the end of April 2014. Twelve research assistants were engaged to distribute the questionnaires to respondents in person according to quota sampling plan, across all the 12 states of West Malaysia. The IBM Statistical Package for Social Science (SPSS) software version 22 was employed to analyze the data gathered in this study. Descriptive statistics was employed to describe demographic characteristics of the respondents. Confirmatory factor analyses (CFA) was undertaken to test the validity and uni-dimensionality of items of brand equity and finally reliability analysis was carried out by gauging the Cronbach's alpha coefficient in order to test the reliability of all questionnaire items

\section{Research findings}

A total of 950 questionnaires were collected back out of which 41 questionnaires were deemed unsuitable, bringing the total usable questionnaires to 909.

\section{Demographics}

Both male and female respondents were almost evenly matched as envisaged in the quota sampling plan. Male respondents had a slight lead over female respondents. Males made up 50.9\% (463 males) of the total population while females made up $49.1 \%$ (446 females) respectively.

There were four age groups of respondents in this research. The highest number of respondents were from 30-39 years age group with a total of 349 (38.4\%) respondents, followed by, 284 (31.2\%) respondents from 20-29 years age group and 179 (16.9\%) from 40-49 years age group respectively. There were only $97(10.7 \%)$ respondents in the 50 years and above age group.

Based on a quota sampling plan, questionnaires were distributed to the targeted sample population comprising Malays (30\%), Chinese (30\%), Indians (30\%) and other Ethnic minorities (10\%), in order to effectively represent consumers from a multi - racial country like Malaysia. However, from the total response received, the highest respondents were Malays with a total of 404 respondents (44.4\%), second highest respondents were Chinese with a total of 249 respondents (27.4\%), followed by Indians with a total of 205 respondents $(22.6 \%)$ and the final group of respondents were 41 (5.6\%), representing other ethnic groups in Malaysia. Other ethnic groups that participated in the research included, Melanau, Kadazan Dusun, Indonesian, Eurasian, Caucasian and Ceylonese.

Questionnaires were equally divided and distributed to both government sector employees and private sector employees (who also included self - employed respondents) as per the sampling plan which indicates $50 \%$ government sector 
respondents and $50 \%$ private sector respondents. However, from the total responses received, the government sector had better response rate at $55.9 \%$ while the private sector had a response rate of 44.1\%. There were slightly more respondents just by over 5.9\% from the government sector and this could also be considered as an evenly received response from both the sectors.

\section{Confirmatory factor analysis for brand equity}

CFA was performed for all the items included in brand equity instrument. The analysis began with the evaluation of appropriateness of the data or correlation matrix for factor analysis. For the data matrix to be appropriate for factor analysis (factorability of the correlation matrix), there must be sufficient number of statistically significant correlations in the matrix, as indicated by Kaiser-MeyerOlkin (KMO) measure of sampling adequacy and Bartlett's test of sphericity. The KMO measure should be at least 0.6 and Bartlett's test of sphericity should be significant $(\mathrm{p}<0.05)$ (Hair et al., 1998; Pallant, 2003). With reference to the values in Table 3, the KMO measure of sampling adequacy is 0.822 and Bartlett's test of sphericity is significant $(\mathrm{p}<0.01)$ which indicates that the matrix meets the assumption of factor analysis and can be factorized.

The four extracted factors matched four component of Brand Equity; brand awareness (BA), brand association (BAS), perceived quality (PQ) and brand loyalty (BL). All items loaded in its respective components with loading values above the specified limit of 0.45 and cross - loadings below 0.35 . The total variance explained by the four factors were $75.64 \%$ which exceeded the minimum value of 0.60 as recommended by Hair et al. (2010).

Table 3. Rotated factor loadings for brand equity

\begin{tabular}{|c|c|c|c|c|c|c|}
\hline \multirow[t]{2}{*}{ Variables } & \multirow{2}{*}{$\begin{array}{l}\text { Items } \\
\text { No. }\end{array}$} & \multirow[t]{2}{*}{ Items } & \multicolumn{4}{|c|}{ Component } \\
\hline & & & 1 & 2 & 3 & 4 \\
\hline \multirow[t]{3}{*}{$\begin{array}{l}\text { Brand } \\
\text { Awareness }\end{array}$} & BA1 & $\begin{array}{l}\text { Organizations exhibiting CSR responsibilities are } \\
\text { better able to build brand awareness. }\end{array}$ & .774 & .167 & .166 & .342 \\
\hline & BA2 & $\begin{array}{l}\text { I am better able to recognize a brand when it is } \\
\text { involved in CSR activities. }\end{array}$ & .728 & .218 & .271 & .290 \\
\hline & BA3 & $\begin{array}{l}\text { A brand that is committed to CSR would easily } \\
\text { be among my top choices. }\end{array}$ & .672 & .261 & .295 & .093 \\
\hline \multirow[t]{3}{*}{$\begin{array}{l}\text { Brand } \\
\text { Loyalty }\end{array}$} & BL3 & $\begin{array}{l}\text { I am more likely to be loyal to a brand } \\
\text { committed to CSR practices. }\end{array}$ & .196 & .791 & .300 & .212 \\
\hline & BL2 & $\begin{array}{l}\text { It is very likely for me to repurchase a brand that } \\
\text { is involved in CSR. }\end{array}$ & .202 & .757 & .259 & .339 \\
\hline & BL1 & $\begin{array}{l}\text { I don't mind paying a higher premium for brands } \\
\text { that are committed to CSR }\end{array}$ & .278 & .754 & .139 & .269 \\
\hline \multirow[t]{4}{*}{$\begin{array}{l}\text { Brand } \\
\text { Association }\end{array}$} & BAS1 & $\begin{array}{l}\text { I can better recall the symbol or logo of a brand } \\
\text { when it is involved in CSR activities }\end{array}$ & .278 & 139 & .754 & .269 \\
\hline & BAS2 & $\begin{array}{l}\text { When an organization is involved in CSR, some } \\
\text { positive characteristics will come to my mind } \\
\text { quickly. }\end{array}$ & .258 & .185 & .747 & .314 \\
\hline & BAS3 & $\begin{array}{l}\text { I can better relate to a brand that has CSR } \\
\text { involvements. }\end{array}$ & .275 & .261 & .734 & .295 \\
\hline & BAS4 & $\begin{array}{l}\text { Brands committed to CSR are seen more } \\
\text { favorably by the society, creating good social }\end{array}$ & .338 & .310 & .629 & .218 \\
\hline
\end{tabular}




\begin{tabular}{|c|c|c|c|c|c|c|}
\hline & & image. & & & & \\
\hline \multirow[t]{3}{*}{$\begin{array}{l}\text { Perceived } \\
\text { Quality }\end{array}$} & PQ3 & $\begin{array}{l}\text { I am more confident of the quality of brands } \\
\text { committed to CSR }\end{array}$ & 257 & .377 & .261 & .716 \\
\hline & PQ2 & $\begin{array}{l}\text { It is very likely for brands committed to CSR to } \\
\text { have products that are functional. }\end{array}$ & .262 & .300 & .310 & .714 \\
\hline & PQ1 & $\begin{array}{l}\text { It is very likely for brands committed to CSR to } \\
\text { have high quality. }\end{array}$ & .352 & .277 & 379 & .580 \\
\hline & \multicolumn{2}{|c|}{ Eigenvalues } & 7.721 & .987 & .584 & .541 \\
\hline & \multirow{2}{*}{\multicolumn{2}{|c|}{$\begin{array}{l}\text { Percentage of Variance Explained } \\
\text { Total Variance Explained }\end{array}$}} & 59.316 & 7.592 & 4.493 & 4.161 \\
\hline & & & \multicolumn{4}{|c|}{$75.64 \%$} \\
\hline & \multicolumn{2}{|c|}{ Kaiser-Meyer-Olkin (KMO) } & & & & \\
\hline & \multicolumn{2}{|c|}{ Bartlett's Test of Spherecity } & \multicolumn{4}{|c|}{$2578.791^{* *}$} \\
\hline
\end{tabular}

Source: Authors' own research results.

\section{Reliability analysis}

Reliability analysis examines the consistency of the items in the event of using multiple measurements of variable (Hair et al., 2010). With reliability analysis, stability of data can be determined. Each separate variable should be measured using the same construct and it is crucial to ensure they are all highly correlated (Hair et al., 2010). Data may be unreliable if these separate variables are not contributing to the overall construct, or in other words, it is measuring something else instead of measuring what it should measure (Bryman \& Bell, 2010).

Reliability is measured using the Cronbach's Alpha by determining the association scores resulted from different administration of scale and ultimately obtain the results for Cronbach's Alpha through the proportion of a systematic variation in the scale. Cronbach's Alpha should surpass 0.50 to be considered acceptable (Bryman \& Bell, 2010). According to DeVellis (2012), ideally a Cronbach alpha coefficient of a scale should be more than 0.7. As demonstrated in table 4, all variables exceeded the recommended 0.7 Cronbach's Alpha value. Thus, it can be concluded that all the measures have acceptable levels of reliability.

Table 4. Cronbach's Alpha for components of brand equity

\begin{tabular}{|c|l|c|c|c|}
\hline \multicolumn{2}{|c|}{ Variables } & $\begin{array}{c}\text { Numbe } \\
\text { rof } \\
\text { Items }\end{array}$ & $\begin{array}{c}\text { Items } \\
\text { Droppe } \\
\text { d }\end{array}$ & $\begin{array}{c}\text { Cronbac } \\
\text { h's Alpha }\end{array}$ \\
\hline \multirow{5}{*}{ Brand Equity } & $\begin{array}{l}\text { Brand } \\
\text { Awareness }\end{array}$ & 3 & - & 0.750 \\
\cline { 2 - 5 } & $\begin{array}{l}\text { Brand } \\
\text { Association }\end{array}$ & 4 & - & 0.860 \\
\cline { 2 - 5 } & $\begin{array}{l}\text { Perceived } \\
\text { Quality }\end{array}$ & 3 & - & 0.853 \\
\cline { 2 - 5 } & Brand Loyalty & 3 & - & 0.850 \\
\hline
\end{tabular}

Source: Authors' own research results.

\section{Implications}


Items for brand equity which were adapted from the multidimensional consumerbased brand equity instrument of Yoo and Donthu (2001) and Yew Leh and Lee (2011) with necessary adaptations to suit a CSR related context were statistically significant and so were the reliability of these items. The findings have confirmed the validity and suitability of this model in a Malaysian context based on the views of Malaysian consumers with the total of $75.64 \%$ variance explained based on the CFA. The findings also seem to highlight that brand equity resulting from increased CSR efforts is potentially related to purchase intention. It is plausible that customers tend to gravitate towards those brands that are associated with CSR. The large sample size covering 12 out of 14 states in Malaysia is indication enough about how the consumers feel about brand equity arising from CSR related efforts.

This survey instrument adds to the current pool of knowledge and references available to researchers especially those focusing on brand equity and CSR related studies. Future researchers can adopt the instrument or make necessary adaptations when carrying out brand equity or CSR related research studies. The study also indicates that the instrument can be used in assessing consumers' perception about the quality of organizations products, how customers identify, relate and associate with the brand and acquire brand preference thus encouraging repeat purchases. The result confirms that the instrument is valid and can be used by organizations that are committed to CSR in order to assess and measure their brand equity. It can also be used as a guideline by organizations that are keen about integrating CSR practices in the way they operate and market their products.

The study also implies the need for organizations and key decision makers to shift their attention to CSR as a legitimate business practice and prerequisite to establishing brand equity and as a means of staying relevant to customers and key stakeholders in a highly competitive business environment. CSR can be presented to business organizations as a route to commercial success while fulfilling the ethical and moral imperative of firms. Appropriate policies, procedures and practices of CSR should therefore be undertaken by Malaysian organization as substantiated by the results of this research study.

The study does not consider any companies or specific industries that is practicing CSR and does not contain the views of industry players, government regulators, corporate leaders and so on. Hence, the results of the study should be treated with caution when applied to any specific industry. Although the instrument is valid based on the CFA, it can also be evaluated and analyzed using the structural equation modeling (SEM) in future studies.

\section{Conclusions}

Based on the results of CFA and reliability analysis, it can be concluded that the 13 item brand equity instrument is valid and can be utilized to measure brand equity of organizations that are committed to CSR in order ascertain if the organization's brands are synonymous with CSR related efforts or what could be perhaps classified as a "CSR Brand". Organizations in Malaysia need to be steadfast in adopting CSR practices and for those organizations that are yet to be convinced about the pay back potential of CSR, the time is ripe for such organizations to strongly consider 
CSR as a means of achieving strategic outcomes in terms of increased reputation and brand equity.

The findings of the research have given a an indication that CSR is indeed a brand enhancing move as substantiated by the views of Malaysian consumers, the very people organizations depend on for continued survival. Effective integration of CSR is expected to help in improving the role of organizations in the society within which they operate and simultaneously reap significant benefits. It was with this in mind that this instrument was developed so as to aid organizations in Malaysia to measure the success of their brand correspondingly with increased CSR efforts.

\section{References}

Aaker, D.A. (1996), "Measuring brand equity across products and markets", California Management Review, Vol. 38, No. 3, pp. 102-120.

Aaker, D.A. (1991), Managing brand equity: Capitalizing on the value of a brand name. New York: Free Press.

Abraham, M. (2001), "Top of mind awareness in industrial markets: Why you need to get and keep it!". Retrieved March 18, 2012 from www.stickymarketing.net/articles/top-of-mind.htm.

Bhattacharya, C.B. and Sen, S. (2003), "Consumer-company identification: A framework for understanding consumer's relationships with companies", Journal of Marketing, Vol. 67, pp. 76-88.

Blumenthal, D. and Bergstorm, A. (2003), "Brand councils that care: Towards the convergence of branding and corporate social responsibility", Journal of Brand Management, Vol. 10, pp. 327 - 341.

Bryman, A. and Bell, E. (2007), Business research methods (2nd ed.). New York: Oxford University Press.

Buil, I., Martinez, E. and de Chernatony (2013), "The influence of brand equity on consumer responses", Journal of Consumer Marketing, Vol. 30, No. 1, 62-74.

Che-Ha, S. and Hashim, N. (2007), "Brand equity, customer satisfaction and loyalty: Malaysian banking sector", International Review of Business Research Papers, Vol. 3, No. 5, pp. 123-133.

Chen, S. and Bouvain, P. (2005), "Branding and corporate social responsibility rankings - doing good is not enough", ANZMAC 2005 Conference: Corporate Responsibility.

Chu, S. and Keh, H.T. (2006), "Brand value creation: Analysis of the InterbrandBusiness Week brand value rankings", Marketing Letters, Vol. 17, pp. 323331.

DeVellis, R.F. (2012). Scale development: Theory and applications (3 ${ }^{\text {rd }}$ ed.). Thousand Oaks, California: SAGE Publications.

Fan, Y. (2005), "Ethical branding and corporate reputation", Corporate Communications: An International Journal, Vol. 10, No. 4, pp. 341-350.

Farquhar, P. H., Han, J. Y. and Iriji, Y. (1991). Recognizing and measuring brand assets, Marketing Science Institute, Cambridge, MA. 91-119.

Fehle, F., Fournier, S., Madden T. and Shrider, D. (2008), "Brand value and asset pricing”, Quarterly Journal of Finance and Accounting, Vol. 47, No. 1, pp. 3-26. 
Hair, J.F., Anderson, R.E., Tatham, R.L. and Black, W.C. (1998), Multivariate data analysis ( $5^{\text {th }}$ ed.), Upper Saddle River: Prentice Hall.

Hair, J.F., Black, W.C., Babin, B.J. and Anderson, R.E. (2010), Multivariate data analysis: A global perspective (7th ed.). New Jersey: Pearson Education Inc.

Hopkins, M. (2006), "What is corporate social responsibility all about?", Journal of Public Affairs, Vol. 6, pp. 298-306.

Hoq, Z., Mohammad, A., Sulaiman, M. and Faridah, S. (2010), "The relationship between ethical brand and company reputation: the Malaysian perspective", Pakistan Journal of Commerce and Social Sciences, Vol. 4, No. 1, pp.100-110.

Jurg, W., Bloemer, J., Doorewaard, H. and Simons, R. (2008), "System constellations: a better way to identify branding opportunities?", Journal of Brand Management, Vol. 15, No. 4, pp. 239-57.

Kapferer, J.-N. (1992), Strategic brand management: New approaches to creating and evaluating brand equity. London: Kogan Page.

Keller, K.L. (1993), "Conceptualizing, measuring and managing customer-based brand equity", Journal of Marketing, Vol. 57, No. 1, pp. 1-22.

Keller, K.L. (2008). Strategic Brand Management (3 $3^{\text {rd }}$ ed.), New Jersey, Prentice Hall Inc.

Key, S. and Popkin, S. (1998), "Integrating ethics into the strategic management process: doing well by doing good", Management Decision, Vol. 36, No. 5, pp. 331-338.

Kumar, V. and George, M. (2007), "Measuring and maximizing customer equity: a critical analysis", Journal of the Academy of Marketing Science, Vol. 35, No. 2, pp. 157-71.

Lassar, W., Mittal B. and Sharma, A. (1995), "Measuring customer-based brand equity”, Journal of Consumer Marketing, Vol. 12, No. 4, pp. 11-19.

Lii, Y.S. (2011), "The effect of corporate social responsibility initiatives on consumers' identification with companies", African Journal of Business Management, Vol. 5, No. 5, pp. 1642-1649.

Luu Trong, T. (2012), "Corporate social responsibility, leadership and brand equity in healthcare service", Social Responsibility Journal, Vol. 8, No. 3, pp. 347-362.

Maneet, K. and Agrawal, S. (2011), "Corporate social responsibility - A tool to create a positive brand image", American Society of Business and Behavioural Sciences, 18th Annual Conference, Las Vegas: February 22-27, 2010. Retrieved from asbbs.org.

Melo, T. and Galan, J. (2009). Effects of corporate social responsibility on brand value. Unpublished Master's Thesis, Spain: Universidad De Salamanca.

Motameni, R. and Shahrokhi, M. (1998), Brand equity valuation: A global perspective". Journal of Product and Brand Management, Vol. 7, No. 4, pp 275290.

Netemeyer, R. G., Krishnan, B., Pullig, C., Dean, D., Ricks, J., Wang, G. and Yagci, M. (2001), Facets of customer based brand equity as a predictor of brandrelated response variables, Working paper, Louisiana State University, Baton Rouge, LA.

Nisen, M. (2013, May 9), “How Nike solved its sweatshop problem”, Business Insider. 
Retrieved

from

www.businessinsider.com/hownikesolveditssweatshopproblem20135?

$\mathrm{IR}=\mathrm{T} \& \mathrm{r}=\mathrm{US} \& \mathrm{IR}=\mathrm{T}$.

O'Cass, A. and Ngo, L.V. (2007), "Market orientation versus innovative culture: two routes to superior brand performance", European Journal of Marketing, Vol. 41, No. 7-8, pp. 868-887.

Oliver, R.L. (1999), "Whence customer loyalty?", Journal of Marketing, Vol. 63, Special Issue, pp. 33-44.

Pallant, J. (2005), SPSS Survival Manual (2nd ed.), London: Open University Press.

Ricks, J.M. (2005), "An assessment of strategic corporate philanthropy on perceptions of brand equity variables", Journal of Consumer Marketing, Vol. 22, No. 3, pp. 121-134.

Sekaran, U. (2000), Research methods for business: A skill building approach. (3rd ed.), New Jersey: John Wiley \& Sons, Inc.

Smith, D.J., Gradojevic, N., and Irwin, W.S. (2007), "An analysis of brand equity determinants: Gross profit, advertising, research and development", Journal of Business \& Economics Research, Vol. 5, No. 11, pp. 103-116.

Subhani, M.I. and Osman, A. (2011), "A study on the association between brand awareness and consumer/brand loyalty for the packaged milk industry in Pakistan", South Asian Journal of Management Sciences, Vol. 5, No. 1, pp. 11-23.

Tsao W.C. and Chen Y.H. (2011), "A study of the impact and application of causecorporate brand alliance on Taiwan's tourist amusement industry", African Journal of Business Management, Vol. 52, No. 2, pp. 316-331.

Wood, D.J. (1991), "Corporate social performance revisited", The Academy of Management Review, Vol. 16, No. 4, pp. 691-718.

Yew Leh, F.C and Lee, G.C. (2011), "Customer based brand equity: A literature review", Journal of Arts Science and Commerce, Vol. 2, No. 1, pp. 33-42.

Yoo, B. and Donthu, N. (2001), "Developing and validating a multidimensional consumer- based brand equity scale”, Journal of Business Research, Vol. 52, No. 1, pp. 1-14.

Zeithaml, V.A. (1988), "Consumer perceptions of price, quality, and value: a meansend model and synthesis of evidence", Journal of Marketing, Vol. 52, No. 3, pp. 222.

Zulhamri, A. and Aziz, Y.A. (2013), "Institutionalizing corporate social responsibility: effects on corporate reputation, culture, and legitimacy in Malaysia", Social Responsibility Journal, Vol. 9, No. 3, pp. 344-361. 